\section{Field Performance of Aliphatic-aromatic Copolyester Biodegradable Mulch Films in a Fresh Market Tomato Production System}

\author{
Mathieu Ngouajio ${ }^{1,3,7}$, Rafael Auras ${ }^{2,4}$, R. Thomas Fernandez ${ }^{1,3}$, \\ Maria Rubino ${ }^{2,4}$, James W. Counts Jr. ${ }^{1,5}$, and \\ Thitisilp Kijchavengkul ${ }^{2,6}$
}

ADDITIONAL INDEX WORDs. biodegradation, polybutylene adipate-co-terephthalate, PBAT, plasticulture, polymers, soil temperature, vegetable production

SUMMARY. Removal and disposal of polyethylene mulch in vegetable production represents a high economic and environmental cost to society. This study was conducted in 2006 and 2007 at Michigan State University to test the field performance of new biodegradable mulches using 'Mountain Fresh Plus' tomato (Solanum lycopersicum) as a model crop. Treatments included two biodegradable mulches (black and white), each with two thicknesses (35 and $25 \mu \mathrm{m}$ ). A conventional low-density polyethylene (LDPE) mulch of $25 \mu \mathrm{m}$ was included as a control (a mulch commonly used by vegetable growers). Data loggers were installed $2 \mathrm{~cm}$ into the soil under the various mulches to record soil temperature. The experiment used a randomized complete block design with four replications. The mulches were used on a raised bed, drip irrigation system. Mulch degradation, soil temperature, tomato growth, weed density, and biomass were assessed during the seasons. Tomatoes were harvested at maturity and were fruit graded according to market specifications. Results indicate that soil temperature under the biodegradable mulches was greater than that under the LPDE mulch during the first week. Starting the second week, soil temperature dropped gradually under all the biodegradable mulches. The drop in temperature was greatest with the white mulch. Due to premature breakdown of the white mulches, weed pressure was high, resulting in smaller plants with low yield in 2007. Tomato growth, yield, and fruit quality from the black mulch was equivalent to that in the LDPE mulch. Future studies will optimize biodegradability of the mulches and test mechanical laying of the black mulch under commercial production.

S ince the early 1950s, commercial fresh market vegetable production has transitioned from bare ground systems to plasticulture in many regions practicing intensive production (Lamont, 2005). Today, production of fresh market vegetables on raised beds covered with plastic mulch and drip irrigated has become a

\footnotetext{
This research was funded in part by Project GREEEN (Generating Research and Extension to meet Environmental and Economic Needs; grant nos. GR05-020D and GR06-089) and by the Michigan Vegetable Council.

We thank William Chase for technical support, and all of the graduate and undergraduate students who helped in this study.

${ }^{1}$ Department of Horticulture, Michigan State University, Plant and Soil Sciences Building, East Lansing, MI 48824

${ }^{2}$ School of Packaging, Michigan State University, Packaging Building, East Lansing, MI 48824

${ }^{3}$ Associate Professor

${ }^{4}$ Assistant Professor

${ }^{5}$ Research Associate.

${ }^{6}$ Graduate Student.
}

${ }^{7}$ Corresponding author. E-mail: ngouajio@msu.edu. standard for most growers worldwide. In 1999, for example, over 30 million acres of agricultural land (over 185,000 acres in the United States) were covered with plastic mulch and the figure has increased significantly since (Miles et al., 2005). It is estimated that $\approx 1$ million tons of mulch film are used worldwide every year in agriculture (Halley et al., 2001). In the United States alone, 130,000 tons of mulch film was used in 2004 (Warnick et al., 2006). Fresh market vegetables that are grown mainly on plastic mulch include bell pepper (Capsicum annuum), muskmelon (Cucumis melo), eggplant (Solanum melongena), slicing cucumber ( $\mathrm{Cucu}$ mis sativus), summer squash (Cucurbita pepo), tomato (Solanum lycopersicum), and watermelon (Citrullus lanatus). The success of plasticulture vegetable production is due to multiple benefits, including early crop maturity, improved yields, high produce quality, reduced weed infestation, better insect management, potential decrease in disease incidence, and efficient use of water and fertilizers. However, one major drawback of plasticulture in vegetable production is the cost and environmental concern associated with the removal and disposal of used plastic. Removal and disposal of used plastic can cost $\$ 250 /$ ha (Shogren, 2000). Several alternatives to reduce this cost have been evaluated by research teams throughout the world. Strategies have varied from the development of biodegradable or degradable mulches to technologies that allow a more efficient recycling or disposal of the used plastic mulch (Feuilloley et al., 2005; Gross and Kalra, 2002; Halley et al., 2001; Ngouajio and Ernest, 2005; Olsen and Gounder, 2001; Sanchez et al., 2008; Shogren, 2000; Vert et al., 2002; Warnick et al., 2006).

Early attempts to develop plastic mulches that breakdown in the field after crop harvest have shown that degradable polymers may produce microfragments that remain in the soil for a long period of time (Feuilloley et al., 2005). A truly biodegradable material should be destroyed by soil microorganisms, bioassimilated, or mineralized (Feuilloley et al., 2005; Gross and Kalra, 2002; Vert et al., 2002). Starch-based polymers have shown enhanced biodegradability, but remain too expensive and sometimes too heavy for agricultural applications (Feuilloley et al., 2005; Halley

\begin{tabular}{llll}
\hline $\begin{array}{l}\text { Units } \\
\text { To convert U.S. to SI, } \\
\text { multiply by }\end{array}$ & U.S unit & SI unit & $\begin{array}{l}\text { To convert SI to U.S., } \\
\text { multiply by }\end{array}$ \\
\hline 0.4047 & $\mathrm{acre}(\mathrm{s})$ & $\mathrm{ha}$ & 2.4711 \\
0.3048 & $\mathrm{ft}$ & $\mathrm{m}$ & 3.2808 \\
2.54 & inch $(\mathrm{es})$ & $\mathrm{cm}$ & 0.3937 \\
0.4536 & $\mathrm{lb}$ & $\mathrm{kg}$ & 2.2046 \\
25.4 & $\mathrm{mil}$ & $\mu \mathrm{m}$ & 0.0394 \\
28.3495 & $\mathrm{oz}$ & $\mathrm{g}$ & 0.0353 \\
0.9072 & $\mathrm{ton}(\mathrm{s})$ & $\mathrm{Mg}$ & 1.1023 \\
$\left({ }^{\circ} \mathrm{F}-32\right) \div 1.8$ & ${ }^{\circ} \mathrm{F}$ & ${ }^{\circ} \mathrm{C}$ & $\left(1.8 \times{ }^{\circ} \mathrm{C}\right)+32$ \\
& & &
\end{tabular}


et al., 2001; Olsen and Gounder, 2001). Paper mulches have also been tested (Sanchez et al., 2008; Shogren, 2000). However, their high costs, heavy weight, and low field performance, especially under adverse conditions (rainfall, high winds, etc.), have limited adoption of those technologies by growers, especially large-scale commercial farmers (Sanchez et al., 2008; Shogren, 2000). More recently, studies have tested the performance of biodegradable materials applied as slurries. These include foam mulches, hydraulic mulches, and hydramulch (Warnick et al., 2006). Those materials are fully degradable, but are expensive, difficult to handle, and require specialized equipment for application. Also, they do not provide the level of weed suppression and soil warming generally achieved with plastic mulch (Warnick et al., 2006).

In the area of new technologies, preliminary studies have shown that baling used plastic may allow growers to reduce the volume and therefore the cost of disposal. Although this technique may allow savings by growers, this does not resolve the environmental issue related to landfilling used plastic and can still cost $\$ 125$ to $\$ 175$ per hectare (Olsen and Gounder, 2001). Another strategy has been double cropping, which allows growing two (or more) crops on the same mulch (Ngouajio and Ernest, 2005). One of the advantages of double cropping is the reduction of the total volume of used agricultural plastic. Unfortunately, this technique cannot be used efficiently in all crops and environments. The possibility of generating energy from used agricultural films is currently being studied; however, this technology is not yet fully developed (Garthe et al., 2006; Lawrence et al., 2006).

The need to develop a plastic mulch with physical, mechanical, and optical performances equivalent to the conventional polyethylene mulch and yet biodegradable over a specific time frame would represent a significant tool to vegetable growers. In previous studies, polybutylene adipate-co-terephthalate (PBAT), an aliphatic-aromatic copolyester polymer, was used to produce biodegradable mulch films with various colors and thicknesses (Kijchavengkul et al., 2006, 2008a, 2008b). The PBAT polymer is known under the commercial name Ecoflex ${ }^{\circledR}$ (BASF, Florham Park, NJ) and its basic chemical structure is shown in Fig. 1. Laboratory tests with corn starch as a control have confirmed the biodegradability of the films (Kijchavengkul et al., 2006, 2008a). However, field testing of the films is necessary to assess their performance in a production system. Therefore, this study was conducted to evaluate the performance of the new PBAT biodegradable mulch films under field conditions using fresh market tomato as a model system.

\section{Materials and methods}

The experiment was conducted at Holt, MI, at the Michigan State University Horticulture Teaching and Research Center. Four biodegradable mulches including two $\mathrm{col}-$ ors (black and white) and two thicknesses per color $(25$ and 35 $\mu \mathrm{m})$ were tested. A conventional 25$\mu \mathrm{m}$ black low-density polyethylene (LDPE) mulch was included in the study as the control. The chemical structure of the biodegradable mulches is shown in Fig. 1. Titanium dioxide and carbon black were used as additives to produce the white and black films, respectively. The biodegradable films were custom made by Northern Technologies International Corp. (Circle Pines, MN). The LDPE film (Pliant Corp. Schaumburg, IL) was purchased from a local supplier. All films were tested in 2006 and 2007 except the $25-\mu \mathrm{m}$ black biodegradable film, which was tested only in 2007. The experimental design was a randomized complete block with four replications and an alley of $3 \mathrm{ft}$ between consecutive blocks. To allow for randomization of the films, the beds were preshaped and drip tape laid using a tractor-mounted bed shaper-mulch layer (model 2600; Rain-Flo Irrigation, East Earl, PA). The mulches were then installed manually and tightly on the beds with the edges buried on 7 June 2006 and 1 June 2007. This procedure allowed simulating film installation with a mulch layer. The beds were about 6 inches tall, 20 inches wide (top), and $5.5 \mathrm{ft}$ on center between beds. Individual plots consisted of one bed $21 \mathrm{ft}$ long with one row of tomato plants spaced 18 inches. This corresponded to a total of 14 plants with the middle 12 plants used for data collection and the two end plants serving as guards. To avoid harvesting guard plants by the harvest crew, the 'Roma'-type tomato variety Mariana was used as guards and the fresh-market variety Mountain Fresh Plus was used for data. The entire experiment was surrounded with one bed of guard plants. Tomato was seeded in 72-cell trays on 11 Apr. 2006 and 20 Apr. 2007 and was kept in the greenhouse for about 6 weeks. Plants were then moved outside for hardening before transplanting. Tomato was transplanted on 7 June 2006 and 5 June 2007. Plants were irrigated at the time of planting and then weekly using a single-pressure compensating drip tape (Aqua-Traxx PC; Toro Micro-Irrigation, Sanford, FL). Temperature sensors (WatchDog 100Temp 2k; Spectrum Technologies, Plainfield, IL) programmed to register temperature every $30 \mathrm{~min}$ were installed $1 \mathrm{~cm}$ into the soil profile between two tomato plants (Ngouajio and Ernest, 2005). Additional sensors were placed $30 \mathrm{~cm}$ above the mulch to record air temperature. Weeds growing between beds were removed by hand as needed, and insects and diseases were controlled following commercial production practices. All treatments were fertigated weekly from mid-June to the first week of September with $20.0 \mathrm{~N}-$ $8.6 \mathrm{P}-16.6 \mathrm{~K}$ to achieve $4 \mathrm{lb} /$ acre nitrogen per week. Leaf chlorophyll content was measured on 5 July 2006 and 28 June 2007 using a chlorophyll meter (SPAD-502; Minolta, Ramsey, $\mathrm{NJ})$. Leaves in similar positions on the

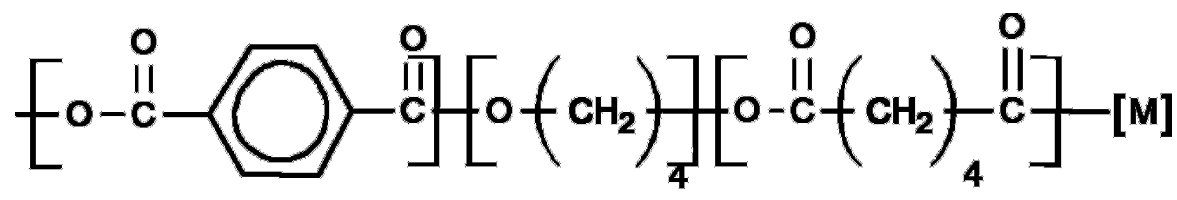

Fig. 1. Structure of polybutylene adipate-co-terephthalate (PBAT) or Ecoflex ${ }^{\circledR}$ (BASF, Florham Park, NJ) material used to produce the biodegradable mulch films used in the field test with tomato at Holt, MI, in 2006 and 2007. 
plant were selected, and 12 measurements were taken in each plot from different plants. Tomato height was measured during leaf chlorophyll assessments. Weed control, density, and biomass were measured throughout each of the growing seasons. Weed control was assessed visually using a scale of $0 \%$ to $100 \%$, with $0 \%$ indicating no weed control and $100 \%$ indicating complete weed suppression. Weed density and dry biomass were measured on an area of $50 \times 50$ $\mathrm{cm}$ in the middle of each bed. Weeds growing in crop holes were removed during the season (standard practice) and therefore did not affect weed control assessments. Mulch degradation was measured during the seasons using a scale of $0 \%$ to $100 \%$, with $0 \%$ indicating no degradation (bed completely covered) and 100\% indicating complete degradation (bed completely exposed). Crop holes were estimated at $5 \%$ and subtracted from mulch degradation data. The trial was harvested on 21 and 31 Aug. and 5, 14 , and 21 Sept. in 2006; and 28 Aug. and 4, 11, 18, and 26 Sept. in 2007. Ratings consisted of weight and count for marketable and unmarketable fruit. All percentage data were square-root-transformed to obtain a normal distribution before analysis, and nontransformed means are presented for clarity. All data were subjected to analysis of variance, and significant differences among means were reported using Fisher protected LSD (least significant difference) at the $5 \%$ level of probability. All statistical analyses were conducted using the PROC GLM (general linear model) procedure of SAS (version 7.1; SAS Institute, Cary, $\mathrm{NC}$ ).

\section{Results and discussion}

The study was conducted in 2006 and 2007 at the same site and all field activities were scheduled about the same time in both years. Nevertheless, the two growing seasons were quite different and produced different responses that resulted in significant year by treatment interactions. Therefore, data are presented by year for the dependent variables.

SoIl AND AIr temperature. Early season air temperature was cooler in 2006 than 2007 (Fig. 2). Early season air temperature is critical for soil warming, weed seed germination, and plant growth. Air temperature
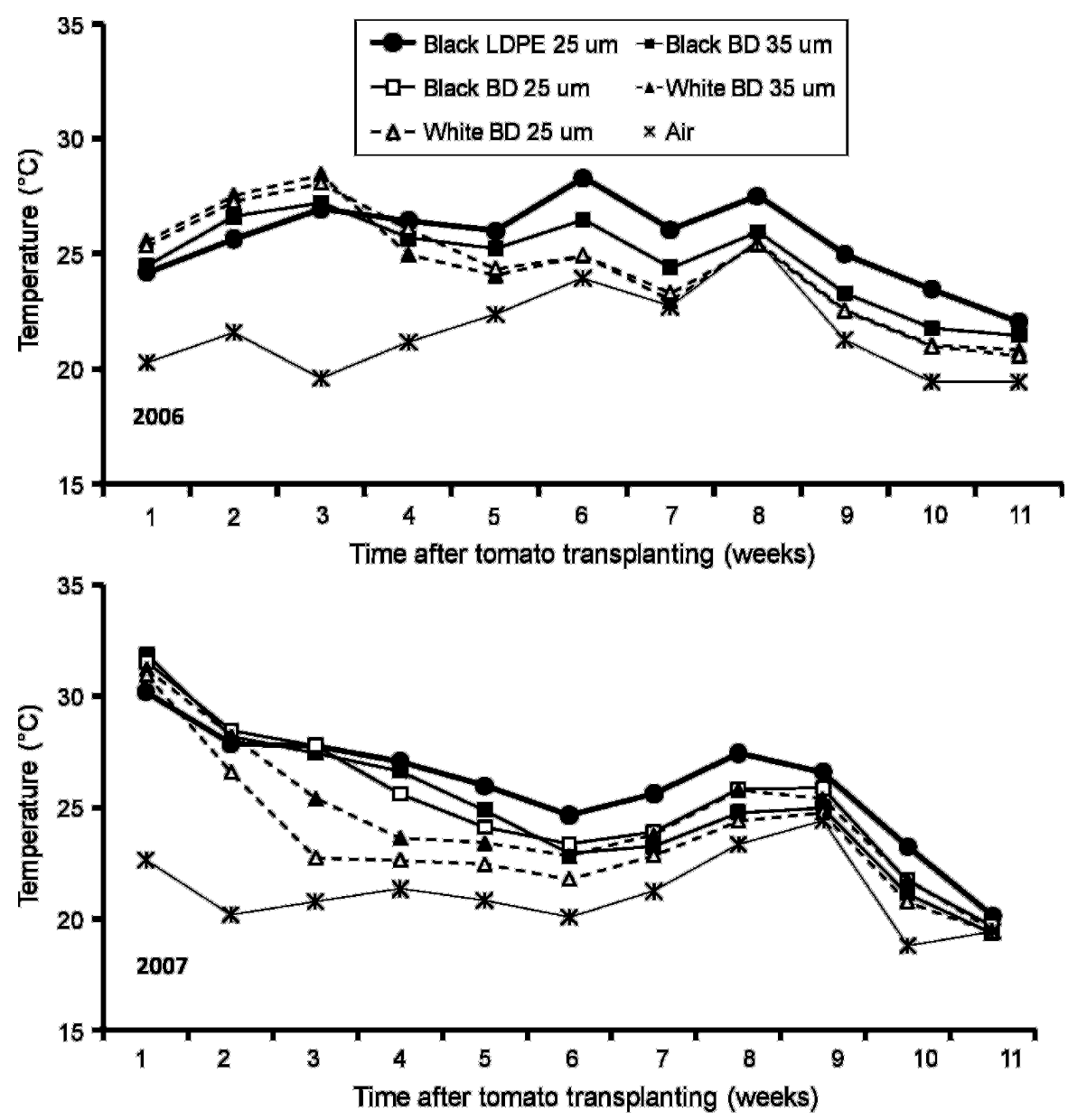

Fig. 2. Soil [ $1 \mathrm{~cm}(0.4 \mathrm{inch})$ deep] and air [30 $\mathrm{cm}$ (11.8 inches) above the soil] temperatures as affected by low-density polyethylene (LDPE) and black and white biodegradable (BD) mulches with various thicknesses (micrometers), during the tomato growing seasons in 2006 and 2007 at Holt, MI. The 25- $\mu$ m black BD mulch was not tested in 2006. Temperature was measured using data loggers (WatchDog 100-Temp 2k; Spectrum Technologies, Plainfield, IL) programmed to recorded values at 30 -min intervals; $\left(18 \times{ }^{\circ} \mathrm{C}\right)+32={ }^{\circ} \mathrm{F}, 1 \mu \mathrm{m}=0.0394 \mathrm{mil}$.

affected soil temperature under the mulches. As expected, soil temperature was generally cooler under the mulches in 2006 early in the season. Overall, the biodegradable (BD) mulches showed higher soil temperature during the first 3 weeks in 2006 and the first week in 2007 compared with the LDPE mulch. However, the differences remained narrow and after that initial period, soil temperature under the $\mathrm{BD}$ mulches dropped below that of the LDPE mulch. The drop in soil temperature was more pronounced with the white $\mathrm{BD}$ mulch in both years, regardless of film thickness. The impact of mulch film color on soil temperature has been reported previously, with white mulches being cooler than darker ones (Diaz-Perez et al., 2005; Lamont, 2005; Ngouajio and Ernest,
2004, 2005; Ngouajio et al., 2003). In the present study, the large drop in soil temperature under the white $\mathrm{BD}$ mulch was probably due to combined effects of mulch color and mulch degradation.

Mulch Degradation. Visual estimation of mulch degradation based on the exposed bed surface showed significant differences among treatments (Table 1). Because of rapid mulch degradation in 2007 , only two evaluations were conducted compared with three evaluations in 2006. The rapid mulch degradation in 2007 was due in part to higher temperatures as indicated above. In both years, the LDPE mulch showed less than $2 \%$ degradation. In most cases, tears in the LDPE mulch were caused by workers and animal (deer and bird) activity. For the BD 
Table 1. Degradation of conventional low-density polyethylene (LDPE) and biodegradable (BD) mulches during field exposure in a tomato production system at Holt, MI, in 2006 and 2007.

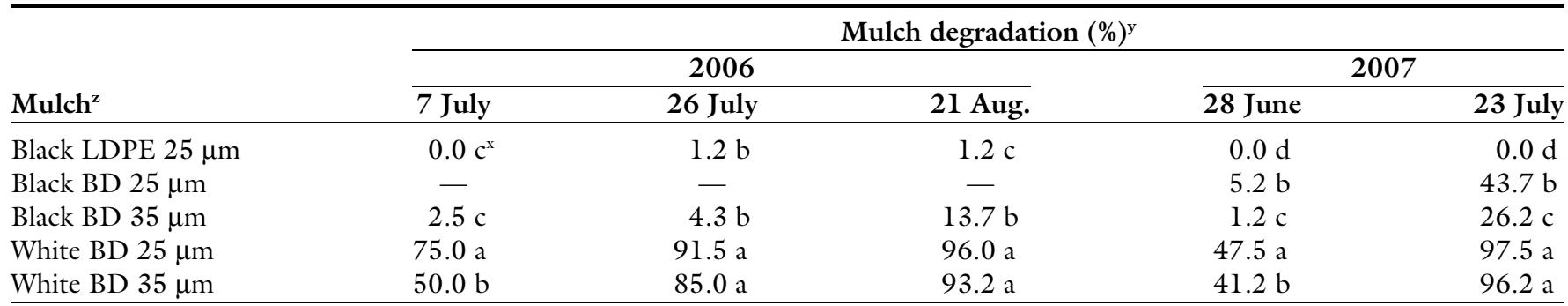

${ }^{2}$ Numbers following treatment names are mulch thicknesses; $1 \mu \mathrm{m}=0.0394$ mil.

${ }^{y}$ Mulch degradation was visually estimated on a scale of $0 \%$ to $100 \%$ as the percentage of bed exposed. Crop holes (5\%) were subtracted from the final values. In 2006,7 July, 26 July, and 21 Aug. corresponded to 31, 50, and $76 \mathrm{~d}$ after mulch laying, respectively. In 2007, 28 June and 23 July, corresponded to 28 and 54 d after mulch laying, respectively. 'Values within a column followed by the same letter are not significantly different at $P=0.05$.

Table 2. Effects of biodegradable (BD) and conventional low-density polyethylene (LDPE) mulches on weed control and biomass in tomato at Holt, MI, in 2006 and 2007.



${ }^{2}$ Numbers following treatment names are mulch thicknesses; $1 \mu \mathrm{m}=0.0394$ mil.

Weed biomass was measured on a $50 \times 50-\mathrm{cm}$ (19.7 inches) area on top of each raised bed; $1 \mathrm{~g}=0.0353 \mathrm{oz}$

'Values within a column followed by the same letter are not significantly different at $P=0.05$.

mulches, thicker mulches showed less degradation early in the season, but late season evaluations did not detect differences based on mulch thickness. The black BD with $35 \mu \mathrm{m}$ was the only material that showed acceptable field life before biodegradation. Only 13.7\% (21 Aug. 2006) and 26.2\% (23 July 2007) of the bed surface was exposed by the first harvest of tomato. The white $\mathrm{BD}$ mulch degraded too fast, exposing the bed for weed growth and competition with tomato.

Weed infestation. Heavier weed infestation occurred in 2007 than 2006. The major weeds were quackgrass (Elymus repens), common lambsquarters (Chenopodium album), and redroot pigweed (Amaranthus retroflexus). The heavy infestation in 2007 was probably a result of warmer temperatures early in the season (Fig. $2)$. This resulted in greater weed biomass in the white BD mulches in 2007 (Table 2). The LDPE mulch provided $100 \%$ weed control in both years, which confirms why this is the preferred mulch used by most vegetable growers. This was followed by the black $35 \mu \mathrm{m}$ and $25 \mu \mathrm{m}$ BD mulch with weed control levels above 97\% and $94 \%$. The white BD mulch

Table 3. Tomato height and leaf chlorophyll content (SPAD values) measured with a chlorophyll meter (SPAD-502; Minolta, Ramsey, NJ), as affected by conventional low-density polyethylene (LDPE) and biodegradable (BD) mulches during 2006 and 2007 at Holt, MI.

\begin{tabular}{lcccc}
\hline & \multicolumn{2}{c}{ Ht $(\mathbf{c m})^{\mathrm{y}}$} & \multicolumn{2}{c}{ SPAD } \\
\cline { 2 - 5 } Mulch $^{\mathbf{z}}$ & $\mathbf{2 0 0 6}$ & $\mathbf{2 0 0 7}$ & $\mathbf{2 0 0 6}$ & $\mathbf{2 0 0 7}$ \\
\hline Black LDPE 25 $\mu \mathrm{m}$ & 46.5 & 29.5 & 59.0 & $55.2 \mathrm{a}^{\mathrm{x}}$ \\
Black BD 25 $\mu \mathrm{m}$ & - & 27.9 & - & $56.5 \mathrm{a}$ \\
Black BD 35 $\mu \mathrm{m}$ & 46.8 & 27.7 & 60.2 & $55.0 \mathrm{a}$ \\
White BD 25 $\mu \mathrm{m}$ & 45.9 & 30.0 & 58.6 & $51.1 \mathrm{~b}$ \\
White BD 35 $\mu \mathrm{m}$ & 46.3 & 28.9 & 59.7 & $50.0 \mathrm{~b}$ \\
\hline
\end{tabular}

${ }^{2}$ Numbers following treatment names are mulch thicknesses; $1 \mu \mathrm{m}=0.0394$ mil.

${ }^{y} 1 \mathrm{~cm}=0.3937$ inch.

${ }^{x}$ Values within a column followed by the same letter are not significantly different at $P=0.05$.

provided poor weed control, regardless of its thickness. Ratings lower than $35 \%$ were recorded as early as 28 June. In commercial production, weed control levels below $85 \%$ are considered unacceptable due to impacts on plant growth, yield, and produce quality (Parks et al., 1995).

Tomato GROWTH AND YIELD. Tomato height was similar in all mulches in the 2006 and 2007 seasons (Table 3 ). However, plants in the white BD mulch treatments were visually smaller and had thin canopy (data not presented). Leaf chlorophyll content was similar for all treatments in 2006 , but was lower for the white BD mulch than other treatments in 2007 . This was likely a direct result of the high weed population (or competition) in 2007. All mulches produced equivalent yields in 2006; however, the white BD mulches had lower yield than the LDPE or black BD mulches in 2007 (Table 4). Unmarketable fruit yield was unaffected by mulch type. However, when measured as a percentage of total yield, the white BD mulches showed a greater proportion of unmarketable fruit compared with other mulches. 
Table 4. Tomato yield and fruit number as affected by conventional low-density polyethylene (LDPE) and biodegradable (BD) mulches at Holt, MI, in 2006 and 2007.

\begin{tabular}{|c|c|c|c|c|c|c|c|c|}
\hline \multirow[b]{3}{*}{ Mulch $^{\mathrm{z}}$} & \multicolumn{4}{|c|}{ Marketable yield ${ }^{y}$} & \multicolumn{4}{|c|}{ Unmarketable yield } \\
\hline & \multicolumn{2}{|c|}{2006} & \multicolumn{2}{|c|}{2007} & \multicolumn{2}{|c|}{2006} & \multicolumn{2}{|c|}{2007} \\
\hline & $\begin{array}{c}\text { No. } \\
\text { (fruit/plot) }\end{array}$ & $\begin{array}{c}\text { Wt } \\
(\mathrm{kg} / \text { plot })\end{array}$ & $\begin{array}{c}\text { No. } \\
\text { (fruit/plot) }\end{array}$ & $\begin{array}{c}\text { Wt } \\
(\mathrm{kg} / \mathrm{plot})\end{array}$ & $\begin{array}{c}\text { No. } \\
\text { (fruit/plot) }\end{array}$ & $\begin{array}{c}\text { Wt } \\
(\mathrm{kg} / \text { plot })\end{array}$ & $\begin{array}{c}\text { No. } \\
\text { (fruit/plot) }\end{array}$ & $\begin{array}{c}\mathrm{Wt} \\
(\mathrm{kg} / \mathrm{plot})\end{array}$ \\
\hline Black LDPE $25 \mu \mathrm{m}$ & 381 & 94.1 & $363 a^{x}$ & $81.7 \mathrm{a}$ & 74 & 14.4 & 40 & 7.3 \\
\hline Black BD $25 \mu \mathrm{m}$ & - & - & 329 a & $75.8 \mathrm{a}$ & - & - & 40 & 7.8 \\
\hline Black BD $35 \mu \mathrm{m}$ & 396 & 95.5 & $341 \mathrm{a}$ & $80.4 \mathrm{a}$ & 91 & 13.4 & 54 & 10.2 \\
\hline
\end{tabular}

${ }^{\mathrm{z}}$ Numbers following treatment names are mulch thicknesses; $1 \mu \mathrm{m}=0.0394 \mathrm{mil}$.

${ }^{y}$ Each plot consisted of one bed $21 \mathrm{ft}$ long $(1 \mathrm{ft}=0.3048 \mathrm{~m})$ with one row of tomato plants spaced $1.5 \mathrm{ft}$ apart ( 14 plants/plot, but only the middle 12 plants were harvested). Beds were spaced on $5.5 \mathrm{ft}$ (centers); $1 \mathrm{~kg}=2.2046 \mathrm{lb}$.

${ }^{x}$ Values within a column followed by the same letter are not significantly different at $P=0.05$.

Overall, the poor performance of the white mulches was due to a combination of factors. They allowed more light transmission, as indicated in laboratory studies (Kijchavengkul et al., 2008a). The high light transmission increased soil temperature and created a microclimate conducive to weed germination (Ngouajio and Ernest, 2005). Weed seedlings under the mulch grew rapidly under warmer conditions, lifted the mulch, and ultimately forced the mulch to tear. Once the mulch was torn, weeds took over and competed with tomato for light, water, and nutrients. The weeds also affected tomato indirectly by hosting a large population of insects that reduced fruit quality. The black $\mathrm{BD}$ mulches, on the other hand, showed excellent field performance. They were comparable to LDPE mulch for soil temperature, weed control, and tomato yield. They started to breakdown near the first harvest of tomatoes. At that time, the critical period for weed control in tomato had already passed, meaning that emerging weeds had limited effect on yield (Salimi et al., 2002; Weaver, 1984).

Despite the high field performance of the black BD mulches, three major things need to be resolved before adoption by vegetable growers. The first constraint is technical and related to the chemistry of the PBAT polymer used to produce the mulch. The biodegradability of the mulch is currently limited due to crosslinking (Kijchavengkul et al., 2008a). This is a process driven by ultraviolet light in which the molecules of the film recombined after initial scission of the main chain and thus prevent biodegradation. Studies using photostabilizers are underway to reduce the impact of this undesirable process. The second limitation is related to practical use of the mulch by farmers. For the mulch to be used by commercial vegetable growers, they need to withstand all mechanical stresses associated with machine application in the field. Laboratory tests have so far shown promising results (Kijchavengkul et al., 2008a, 2008 b). However, these results need to be confirmed in the field under large-scale production systems. The third limitation is related to the overall economics of the new mulch. It will be critical to produce a material with an acceptable cost. Because the biodegradable technology allows significant savings for removal and disposal of used mulch (about \$250/ ha), it is acceptable to have a higher price for biodegradable mulches compared with LDPE mulches. However, the price of the biodegradable mulch should stay within limits economically acceptable for this technology to make its way into commercial vegetable production.

\section{Literature cited}

Diaz-Perez, J.C., S.C. Phatak, D. Giddings, D. Bertrand, and H.A. Mills. 2005. Root zone temperature, plant growth, and fruit yield of tomatillo as affected by plastic film mulch. HortScience 40:13121319.

Feuilloley, P., G. Cesar, L. Benguigui, Y. Grohens, I. Pillin, H. Bewa, S. Lefaux, and M. Jamal. 2005. Degradation of polyethylene designed for agricultural purposes. J. Polymer Environ. 13:349-355.

Garthe, J.W., B.G. Miller, W.J. Lamont, and M.D. Orzolek. 2006. Air emissions from fuel made of used agricultural plastics. 17 May 2008. <http://www.plasticulture. org / Research Papers / A ir \% 20 Emissions\%20from\%20Fuel\%20Made\% 20 of $\% 20$ Used $\% 20$ Agricultural $\% 20$ Plastics.htm $>$.

Gross, R. and B. Kalra. 2002. Biodegradable polymers for the environment. Science 297:803-807.

Halley, P., R. Rutgers, S. Coombs, J. Kettels, J. Gralton, G. Christie, M. Jenkins, H. Beh, K. Griffin, R. Jayasekara, and G. Lonergan. 2001. Developing biodegradable mulch films from starchbased polymers. Starch/Starke 53:362367.

Kijchavengkul, T., R. Auras, M. Rubino, M. Ngouajio, and R.T. Fernandez. 2006. Development of an automatic laboratoryscale respirometric system to measure polymer biodegradability. Polymer Testing 25:1006-1016.

Kijchavengkul, T., R. Auras, M. Rubino, M. Ngouajio, and R.T. Fernandez. 2008a. Assessment of aliphatic-aromatic copolyester biodegradable mulch films. Part I: Field study. Chemosphere 71: 942-953.

Kijchavengkul, T., R. Auras, M. Rubino, M. Ngouajio, and R.T. Fernandez. 2008b. Assessment of aliphatic-aromatic copolyester biodegradable mulch films. Part II: Laboratory simulated conditions. Chemosphere 71:1607-1616.

Lamont, W.J. 2005. Plastics: Modifying the microclimate for the production of vegetable crops. HortTechnology 15: $477-481$.

Lawrence, M.J., J.W. Garthe, and D.R. Buckmaster. 2006. A new look at making plastic-derived fuel: The Plastofuel 500. 17 May 2008. <http://www.plasticulture. org/ResearchPapers/A\%20 New\%20 Look\%20at\%20Making\%20 PlasticDerived $\% 20$ Fuel.htm $>$. 


\section{Research Reports}

Miles, C., L. Garth, M. Sonde, and M. Nicholson. 2005. Searching for alternatives to plastic mulch. 17 May $2008<$ http:// biobagusa.com/MulchReport.pdf>.

Ngouajio, M. and J. Ernest. 2004. Light transmission through colored polyethylene mulches affects weed populations. HortScience 39:1302-1304.

Ngouajio, M. and J. Ernest. 2005. Changes in the physical, optical, and thermal properties of polyethylene mulches during double cropping. HortScience 40:94-97.

Ngouajio, M., R. Goldy, S. Snapp, and B. Zandstra. 2003. Effect of colored polyethylene mulch on fresh market tomato growth and yield. Proc. 31st Natl. Agr. Plastics Congr. p. 100-105.

Olsen, J.K. and R.K. Gounder. 2001. Alternatives to polyethylene mulch film:
A field assessment of transported materials in capsicum (Capsicum annumm L.). Austral. J. Expt. Agr. 41:93-103.

Parks, R.J., W.S. Curran, G.W. Roth, N.L. Hartwig, and D.D. Calvin. 1995. Common lambsquarters (Chenopodium album) control in corn (Zea mays) with postemergence herbicides and cultivation. Weed Technol. 9:728-735.

Salimi, H., H. Rahimian, and D. Shahriary. 2002. Determination of the critical period of weed control in tomato. J. Plant Dis. Protection 18:511-518.

Sanchez, E., W.J. Lamont, Jr., and M.D. Orzolek. 2008. Newspaper mulches for suppressing weeds for organic high-tunnel cucumber production. HortTechnology 18:154-157.
Shogren, R.L. 2000. Biodegradable mulches from renewable resources. J. Sustainable Agr. 16:33-47.

Vert, M., I.D. Santos, S. Ponsart, N. Alauzet, J.L. Morgat, J. Coudane, and H. Garreau. 2002. Degradable polymers in a living environment: Where do you end up? Polym. Int. 51:840-844.

Warnick, J.P., C.A. Chase, E.N. Rosskopf, E.H. Simonne, and J.M. Scholberg. 2006. Weed suppression with hydramulch, a biodegradable liquid paper mulch in development. Renewable Agr. Food Systems 21:216-223.

Weaver, S.E. 1984. Critical period of weed competition in three vegetable crops in relation to management practices. Weed Res. 24:317-325. 